\section{CIRRIFORM CLOUDS}

I N a "Note on a Proposed Scheme for the Observation of the Upper Clouds" the Rev. W. Clement Ley has written an abstract of part of a large work on clouds, which he is now preparing for publication. This note has been circulated with a view of obtaining suggestions on the scheme of classification, observation, and telegraphy, which the writer has submitted to his colleagues of the Committee on Cirrus observations, nominated by the International Meteorological Committee in 1882.

The author follows the primary outlines of cloudclassification proposed by Luke Howard, dividing the objects of observation into cirriforms, cumuliforms, stratiforms, and cornposites; while in the subdivision of these primary types he has been induced by reasons, the cogency of which he hopes to demonstrate, to deviate very considerably from Howard's classification. The true cirriforms, to the discussion of which the note is restricted, are divided by $\mathrm{Mr}$. Ley as follows: cirrus, cirro-filum, cirro-velum (with its variety mammatum), cirro-nebula, and cirro-granum. The author has been, "after many years devoted to the consideration of the subject, reluctantly compelled to give up the employment of the two terms 'cirro-stratus' and 'cirro-cumulus.' Their use has led to endless confusion. In point of structure the clouds usually called cirro-cumuli belong essentially to the higher stratiforms, consisting of nubecules separate, or partly coalescing, occupying a layer of atmosphere of very small vertical thickness, but of very great horizontal extent, and they are not formed in nature by those processes which are productive of clouds either of the cirrus or of the cumulus type. They are not, in fact, either in appearance or in mode of physical formation, either compounds of cirrus with cumulus or hybrids between cirrus and cumulus. Therefore in practice the use of the word cirro-cumulus has led to a large number of clouds of no great elevation being classified among the cirriforms, a result which was of little consequence when the laws regulating the upper currents of the atmosphere had received no examination, but which must be absolutely fatal to a scheme based upon those laws, according to which new and most valuable results will be attained. The name cirro-stratus is almost equally objectionable, and for similar reasons."

Six pages of this note are devoted to instructions on a system of observing and reporting by telegraph the structure and movements of the upper clouds; and the author shows that, if this system be adopted on an extensive scale, results of great practical importance may be anticipated. The indispensable pre-requisite is a clear and scientific classification of clouds according to physical structure.

\section{SCIENTIFIC PROGRESS IN CHINA AND $\mathcal{F} A P A N$}

VARIOUS steps in the progress of China and Japan in the adoption of Western science and educational methods have from time to time been noticed in these columns. To the popular mind the names of the two countries are synonymous with rigid unreasoning conservatism and with rapid change respectively. The grave, dignified Chinese, who maintains his own dress and habits even when isolated amongst strangers, and whose motto appears to be, Stare super vias antiquas, is popularly believed to be animated by a sullen, obstinate hostility towards any introduction from the West, however plain its value may be; while his gayer and more mercurial neighbour, the Japanese, is regarded as the true child of the old age of the West, following assiduously in its parent's footsteps, and pursuing obediently the path marked out by European experience. There is considerable misconception in this, as indeed there is at all times in the English popular mind with regard to strange peoples. Broadly speaking, it is no doubt correct to say that Japan has adopted Western inventions and scientific appliances with avidity ; that she has shown a desire for change which is abnormal, and a disposition to destroy her charts and sail away into unsurveyed seas, while China remains pretty much where she always was. She is now, with some exceptions, what she was twenty, two hundred, perhaps two thousand years ago, while a new Japan has been created in fifteen years. All this, we say, is true, but it is not the whole truth. China also has had her changes; not indeed so marked or rapid, not so much in the nature of a volte-face on all her past as those of her neighbour. The radical difference between the two countries in this respect we take to be this: that while Japan loves change for the sake of change, China dislikes it, and will only adopt it when it is clearly demonstrated to her that change is absolutely necessary. To the Japanese change appears to be a delightful excitement, to the Chinese a distasteful necessity ; to the former whatever is must be wrong, to the latter whatever is is right. As a consequence of this difference between the two peoples, when China once makes a step forward it is generally after much deliberation, and is never retraced. Japan is constantly undertaking new schemes with little care or thought for the morrow, but with the applause of injudicious foreign friends. In a short time she discovers that she has underrated the expense or exaggerated the resulis, and her projects are straightway abandoned as rapidly and thoughtlessly as they were commenced. Swift suggested as a suitable subject for a philosophical writer a history of human projects which were never carried out ; the historian of modern Japan finds these at every turn. Where, for example, are the results of the great surveys, trigonometrical and others, which were commenced in Yezo and the main island about ten years ago? A large, expensive, but highly competent foreign staff was engaged, and worked for a few years; but suddenly the whole survey department was swept away, and the valuable instruments are, or were recently, lying rusting in a warehouse in Tokio. The same story may be told of scores of other scientific or educational undertakings in Japan. An able and careful writer, Col. H. S. Palmer, R.E., who has recently, with a friendly and sympathetic eye, examined the whole field of recent Japanese progress, in the British Quarterly Review, is forced to acknowledge this. "Once having recognised," says this officer, "that progress is essential to welfare, and having resolved, first amongst the nations of the East, to throw off past traditions and mould their civilisation after that of Western countries, it was not in the nature of the lively and impulsive Japanese to advance along the path of reform with the calmness and circumspection that might have been possible to a people of less active temperament. Without doubt many foreign institutions were at first adopted rather too hastily, and the passing difficulties which now beset Japan are to some extent the inevitable result." It would be blindness to deny that the net result of the Japanese efforts is progress of a very remarkable kind, but it is a progress which in many respects lacks the firm and abiding characteristics of Chinese movements.

The proverb, Chi va piano va sano, which was recom. mended ten years ago to Japanese attention by an eminent English official, and apparently disregarded by them, has been adopted by their continental neighbours. To the blandishments of pushing diplomatists or acute promoters, the Chinese are deaf. However we may felicitate ourselves on our inventions, scientific appliances, "the railway and the steamship and the thoughts that shake mankind," our progress, the newspapers, the penny post, and what not, China will not adopt them simply because we have found their value and are proud of them. But if, within the range of her own experience, she finds the advantage of these things; she will employ them with a 